\title{
Whistle-blower claims his accusations cost him his job
}

\author{
University denies it retaliated against researcher who questioned supervisor's data.
}

\section{BY EUGENIE SAMUEL REICH}

A fter months of friction that culminated in his openly questioning the reproducibility of data published by his supervisor, a postdoc at the University of Wisconsin-Madison's zoology department was presented with three options. The department's chairman said he could wait to be fired, resign voluntarily or accept a "gracious exit strategy" that would give him time to prepare a paper for publication, if he dropped his "scientific misconduct issues".

When geneticist Aaron Taylor objected that the third option sounded like a "plea bargain" meant to discourage him from pressing his concerns about the lab's data, the chairman, Jeffrey Hardin disagreed. But Hardin also said: "I think you'd have to decide which is more important to you." He later added: "You have to decide whether you want to kind of engage in whistle-blowing."

Taylor recorded the November 2009 exchange without Hardin's knowledge something permitted under Wisconsin law. Although Taylor declined to make a decision in the meeting, he resigned a few days later, minutes before a disciplinary meeting at which he would have been fired. He says he lost his job because he voiced doubts about data published by the lab of Yevgenya Grinblat, the faculty member who employed him. Grinblat, whose scientific conduct has been upheld by the university and who is not under investigation, says that Taylor lost his job because of a "disrespectful attitude".

The story illustrates a problem that can arise when a junior researcher comes into conflict with a senior colleague over research integrity. Whistle-blowers are supposed to be protected from retaliation, even if they are wrong, as long as they are acting in good faith. Yet, when personality clashes enter the mix - a likely scenario when accusations begin to fly - the outcome can be much less clear cut.

In Taylor's case, Hardin strongly denies any retaliation, and says that a move was made to terminate Taylor's contract for "serious personnel issues". E-mails provided by Grinblat show that she had mentioned and sought advice about what she said was Taylor's negative attitude to colleagues inside and outside the

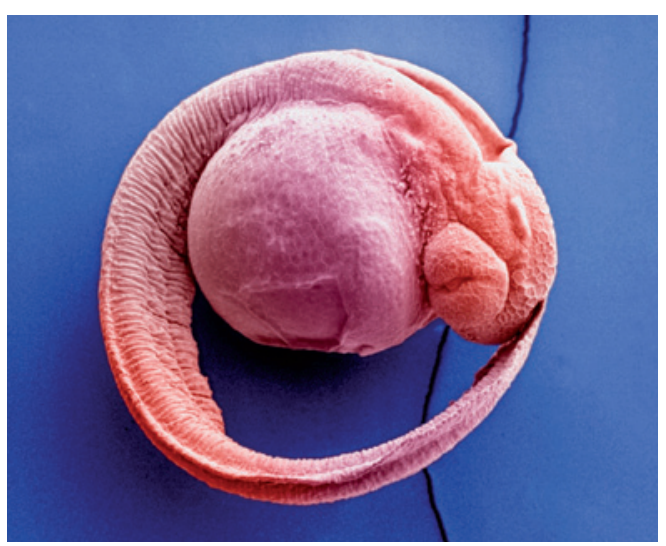

Zebrafish embryos are at the centre of a dispute over research integrity.

university before he questioned her data. Even so, an e-mail from Hardin to Eric Wilcots, an associate dean for mathematical and natural sciences at the university, seems to imply that Taylor's accusations played a part in his departure. The e-mail said that Taylor had engaged in "seemingly inappropriate correspondence" - referring to a caustic e-mail to Grinblat in which Taylor alleged that she acted improperly as a researcher and a lab supervisor.

C. K. Gunsalus, a lawyer and expert on research misconduct at the University of Illinois in Urbana-Champaign, who read documents provided by the university at Nature's request, says: "On the face of it, the university's actions at least raise a question as to whether there was retaliation for speaking out."

Reprisal against whistle-blowers is banned by the US federal policy on research misconduct, which guides how allegations should be handled by institutions that receive grant money from the government, which Grinblat's lab does. The University of Wisconsin also has a policy that explicitly protects whistleblowers from retaliation. Taylor says that his experience therefore holds a lesson for those who wish to question a supervisor's work: being explicit about suspicions and citing relevant statutes when making allegations might help to prevent reprisals.

Taylor was studying zebrafish development in Grinblat's lab when he became concerned about work the lab was submitting for publication. In one paper (Development 136, 3791-3800; 2009), on which he was listed as a co-author, Taylor felt that images of zebrafish embryos that were being used to illustrate changes in the expression of particular proteins had been chosen without quantitative support. E-mail records show that he queried the data with Grinblat, but they were nevertheless submitted for publication. Grinblat responds that the use of the images followed standard methods and is based on repeatable experiments. She adds that the quantification method Taylor may have wanted to use was not sensitive enough to detect the changes in gene expression they were observing.

Taylor says that he now cannot prove that the images amounted to falsification because he does not have access to the raw data. He requested access under Wisconsin's

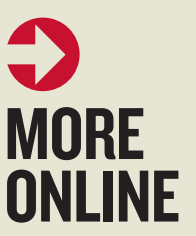

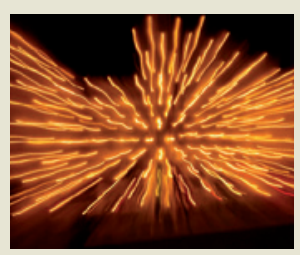

Moving mirrors make light from nothing go.nature.com/ gz2w8p

\section{OTHER NEWS}

- Less than $10 \%$ of tropical forests are managed sustainably go.nature.com/ aepg40

- Chronic fatigue syndrome: life after XMRV go.nature.com/eoyxk1

- Did some human ancestors evolve in Europe? go.nature.com/ocjv3v

\section{EXPLAINER}

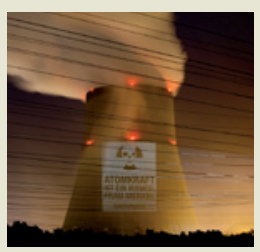

The knock-on effects of Germany's nuclear phase-out go.nature.com/ wordrf 
public-records laws, but the university declined to release them, in part because it determined that releasing a faculty member's data would violate academic freedom.

Some months after they disagreed on the images, matters came to a head when Grinblat asked Taylor to provide a detailed protocol for a lab technique. Taylor accused her of repeatedly pressuring him to publish data that he considered unreliable, and threatened to bring a case against her to the dean. Soon after, he wrote to Hardin saying that he had doubts about the reproducibility and reliability of work published by the lab.

When asked about Taylor's charges of being pressured, Grinblat says she gave him a deadline because she felt that was the only way to get him to publish his good data. Grinblat comments that, in general, Taylor was extraordinarily reluctant to publish his work.

\section{DIFFERENCE OF OPINIONS}

Taylor's former PhD supervisor, neuroscientist Justin Fallon at Brown University in Providence, Rhode Island, says that Taylor is a smart and original thinker who worked independently in his lab and published his work expeditiously. "He worked in a professional and efficient manner," Fallon says, adding that he doesn't agree with the suggestion that Taylor is difficult in the lab.
A letter to Taylor provided by the university says that Wilcots reviewed the evidence that Taylor submitted and talked with him and others before deciding that his complaints did not meet the university's criteria for research misconduct. "What he was presenting was a difference of opinion with his co-author on the significance of results," Wilcots says. However, Wilcots says that he did not look at the raw data from the zebrafish experiments before making that decision. Nor did "Youhave to the university hold an decide whether investigation into the you want to kind of engage in whistleblowing." matter.

Gunsalus says that her interpretation of the documentation is that Taylor's concerns included allegations of misconduct, and would warrant an inquiry.

Because the university asserted that he was not fired, Taylor was not entitled to unemployment benefits in Wisconsin. He therefore filed a complaint with the state's Department of Workforce Development, which ruled that, counter to the university's statements, his departure was not voluntary. In 2010, he also filed a complaint of whistle-blower retaliation with the department, but dropped the case after he took a job at an institution in another state.

Taylor subsequently forwarded his charges and concerns to the Office of Research Integrity (ORI), which oversees allegations of misconduct in research funded by the National Institutes of Health. The ORI told Taylor in 2010 that it was looking into whether the university had investigated adequately, but would not pursue the allegation of retaliation because Taylor had filed a case at the Department of Workforce Development, even though the case was not longer active.

Wisconsin's associate dean for research policy, William Mellon, says that he did receive a phone call from the ORI about the case, but no further inquiry has been made.

The timing of Taylor's termination and the clash of personalities suggest that extra care was needed to avoid an ambiguous outcome. But Mellon expresses surprise at the suggestion that the university did not act appropriately. $\mathrm{He}$ says that the university does take a firm stance on misconduct when it is warranted. "But when it doesn't meet the standard, there are no actions for us to take," he says. Taylor says he has been able to put the situation behind him and is happy at his new institution, which Nature agreed not to name, but he remains disillusioned with the way his situation was handled by his former employer.

"It is critical for the integrity of science that universities are not allowed to retaliate against whistle-blowers," he says. 